\title{
THE ASSOCIATION BETWEEN ERa/ Bg/l GENOTYPES AND MILK PERFORMANCE IN HOLSTEIN-FRIESIAN AND JERSEY CATTLE. PRELIMINARY STUDY
}

\section{ZWIAZEK MIĘDZY GENOTYPAMI ERa/ Bgll A WYDAJNOŚCIĄ MLECZNĄ KRÓW RAS HOLSZTYŃSKO-FRYZYJSKIEJ I JERSEY. BADANIA WSTĘPNE}

Department of Molecular Cytogenetics, West Pomeranian University of Technology, Szczecin, Poland

\begin{abstract}
Streszczenie. Selekcjonując zwierzęta do dalszej hodowli powinno się brać pod uwagę wiele czynników, takich jak fenotypowe i genotypowe cechy osobnika. Selekcja wspierana markerami (ang. marker-assisted selection, MAS) jest narzędziem przydatnym do oceny genetycznej wartości zwierzęcia. Do tej pory wykryto i opisano wiele czynników genetycznych, które są odpowiedzialne za wydajność produkcji zwierzęcej. Badaniami objęto związek pomiędzy genotypami $E R \alpha / B g / l$ a wydajnością mleczną krów. Przebadano dwie rasy krów (jersey i holsztyńsko-fryzyjską odmiany czerwono-białej); otrzymane wyniki wskazują, że polimorfizmy badanego genu mogą wpływać na wydajność mleczną tych dwóch ras. Zidentyfikowano trzy genotypy: GG, $A G$ i $A A$. Rezultaty dotyczące wydajności mlecznej obu stad wskazują, że najwyższą wydajnością mleczną charakteryzują się krowy o genotypie $G G$, a najmniejszą - heterozygoty $A G$. Otrzymane wyniki mogą sugerować istnienie związku pomiędzy wariantami polimorficznymi genu $E R \alpha / B g / l$ a wydajnością mleczną krów. W celu potwierdzenia związku między analizowanymi cechami polimorficznymi badanego genu a cechami mleczności trzeba przeprowadzić badania na większej populacji krów, przy wykorzystaniu informacji dotyczących kolejnych laktacji i/ lub całej produkcji życiowej.
\end{abstract}

Key words: $E R \alpha$, cattle, holstein-friesian, jersey, milk yield, milk production, estrogen receptor. Słowa kluczowe: $E R \alpha$, bydło, holsztyńsko-fryzyjska, jersey, wydajność mleczna, receptor estrogenowy.

\section{INTRODUCTION}

Quantitative traits are known to be the most important factors from an economic point of view when it comes to breeding farm animals. The traits of this nature are most commonly polygenic and are distributed throughout the genome. Because of this, direct gene mapping and locating the markers is difficult (Lande and Thompson 1989). Marker-assisted selection (MAS) is recommended to understand polygenic differences with phenotypic quantitative traits. Farmers can optimise their herd selection by looking at data that concerns both, genetic and phenotypic, factors. According to this, results of the following study can be used to widen the database of already known markers linked with milk yield in cattle.

Corresponding author - Adres do korespondencji: Małgorzata Wasielewska, Department of Molecular Cytogenetics, West Pomeranian University of Technology, Szczecin, Klemensa Janickiego 29, 71-270 Szczecin, Poland, e-mail: malgorzata.wasielewska@zut.edu.pl 
Estrogen receptors (ER) are localised to the nucleus where they act as an important transcription factor and participate in many physiological processes. The receptor can be found in two isoforms: ER $\alpha$ and ER $\beta$, where the ERa form is a dominant one. (Nowaka and Zawiska 2004). The bovine ERa gene is made of 8 exons, separated by 7 introns and, importantly, is localised in four chromosomes $(9,10,15$ and 29) near to the microsatellite marker BMS2295, on 98.6cM (according to the USDA mapping). (Connor and Wood 2005). The regulatory sequence of the gene is typical for proteins of similar function and has typical CAAT and TATA boxes. In this region in cattle there appears sequential diversity, which can influence the expression level of the gene. (Manavathi and Kumar 2006)

Receptors in the nucleus are connected to a large complex of various chaperon proteins and, in particular, heat shock proteins (HSP). Thanks to this, it is possible for the proteins to remain in an inactive form while at the same time still be able to bind with the ligand. After a successful binding, the ER dissociates from the complex, which is obligatory for dimerization and necessary for creation of a functional transcription factor. In the next step, the ER dimers bind with palindromic DNA sequences known as the 'estrogen responsible element'. The ERa mRNA transcripts are localised in many organs: uterus, ovaries, prostatic gland, heart, liver, kidneys and mammary gland. In matured cattle ERa expression takes place in epithelial cells of the mammary gland during lactation, although the expression is perhaps minimal during pregnancy and involution (Capuco and Meyer 2006).

Considering the function, location and the time of expression, the purpose of the following study is to describe the frequency of $E R \alpha / B g / l$ genes and genotypes in two breeds of cattle (Jersey and Holstein-Fresian red and white) and an attempt to associate particular polymorphisms with chosen traits, typical for milk production.

\section{MATERIAL AND METHODS}

For the research blood was drawn from external jugular vein of 300 cows of two breeds (150 Holstein-Friesian red and white (HF) and 150 Jerseys), kept in Opole Voivodeship and Wielkopolskie Voivodeship. The blood was drawn during routine veterinary examinations and placed in tubes containing EDTA anticoagulant. DNA was isolated from the samples taken using the MasterPure Genomic DNA Purification Kit made by Epicenter Technologies. The method supplied by the producer was followed.

The Polymerase Chain Reaction (PCR) mix contained approximately $50 \mathrm{ng}$ of DNA template, 0.3 units DreamTaq DNA Polymerase (Thermo Scientific), 1x PCR Buffer (Thermo Scientific), $1.5 \mathrm{mM} \mathrm{MgCl} 2,200 \mu \mathrm{M}$ each dNTP, $15 \mathrm{pM}$ of each primer and made up to $15 \mu \mathrm{L}$ with deionized water.

The following primer sequences were modelled using the computer program PRIMER 3: F 5'-TTTGGTTAACGAGGTGGAG-3', R 3'-TGTGACACAGGTGGTTTTC-5'.

Thermocycler conditions were as follows: denaturation at $94^{\circ} \mathrm{C} / 5 \mathrm{~min}$, followed by 34 cycles of three steps: denaturation at $94^{\circ} \mathrm{C} / 30 \mathrm{~s}$, primer annealing at $54^{\circ} \mathrm{C} / 30 \mathrm{~s}$, amplicon synthesis at $72^{\circ} \mathrm{C} / 30 \mathrm{~s}$ and then final synthesis at $72^{\circ} \mathrm{C} / 5 \mathrm{~min}$. Specificity and efficiency of 
the amplification by the PCR $(4 \mu \mathrm{l})$ was evaluated by electrophoresis of the products in $1.5 \%$ agarose gels (Syngen) in $1 \times$ TBE for $20 \mathrm{~min}$ at $130 \mathrm{~V}$. The PCR products $(11 \mu \mathrm{l})$ were digested with 2 units of $B g / l$ (Thermo Scientific ${ }^{\mathrm{TM}}$ ) restriction endonuclease which recognized TAC $\downarrow$ GTA sites and cut at $37^{\circ} \mathrm{C}$ for $4 \mathrm{~h}$. The digestion reaction contained also $2 \mu \mathrm{L} 10 \times$ Tango buffer and $\mathrm{H}_{2} \mathrm{O}$ to make up to a total volume of $20 \mu \mathrm{L}$. After incubation, the digested fragments were electrophoresed on $2 \%$ agarose gel stained with ethidium bromide in $1 \times$ TBE for $50 \mathrm{~min}$ at $130 \mathrm{~V}$. Results of the gels showing the ER1 genotypes were viewed under UV light.

\section{STATISTICAL ANALYSES}

Statistical analyses were performed using the appropriate $R$ packages ( $R$ Core team, 2015). An additive relationship matrix was constructed based on the three-generation pedigree using the kinship2 $\mathrm{R}$ package. The following linear model was constructed and estimated using the Imekin function in the coxme $\mathrm{R}$ package:

$$
Y=\mu+G+H+Y S+\beta_{1} A+\beta_{2} L+\alpha+e
$$

where:

$Y-$ the phenotypic value of each trait,

$\mu-$ the overall mean,

$G$ - the fixed effect corresponding to the genotype of the polymorphisms,

$H$ - the fixed effect of herd,

$Y S$ - the fixed effect of the year-season of calving,

$\beta_{1} A$ - the regression coefficient for the age of a cow,

$\beta_{2} L$ - the regression coefficient for lactation length,

$\alpha-$ a random polygenic component accounting for all known pedigree relationships,

$e-a$ random residual.

In the analyses performed simultaneously for all three lactations the fixed effect of lactation was also included. Bonferroni's correction was applied for multiple comparisons.

\section{RESULTS AND DISCUSSION}

\section{The frequency of alleles and genotypes}

In the result of PCR, there were amplified DNA fragments 242bp long (Fig. 1), containing the SNP studied. In the herds tested, there were three genotypes identified which are related to the $\mathrm{G}>\mathrm{A} E R \alpha$ transition (identified with $B g / l$ restriction enzyme): $G G$ (two fragments: 182bp and 60bp), GA (three fragments: 242bp, 182bp, 60bp) and $A A$ (one fragment: 242bp) - Fig. 2.

Gels were run to ascertain which genotype an individual cow had which could be linked back to the data about milk production values obtained from the farmers.

The frequency of each genotype and allele was calculated according to the Hardy-Weinberg theorem and are shown in the Table 1. 


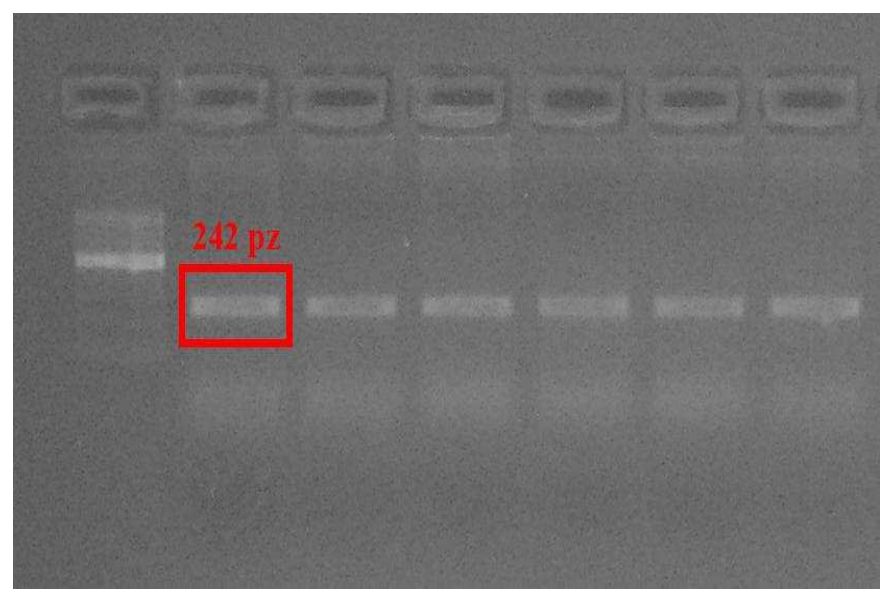

Fig. 1. The product of the PCR, the product's length $-242 \mathrm{bp}$

Ryc. 1. Produkt PCR o długości 242pz

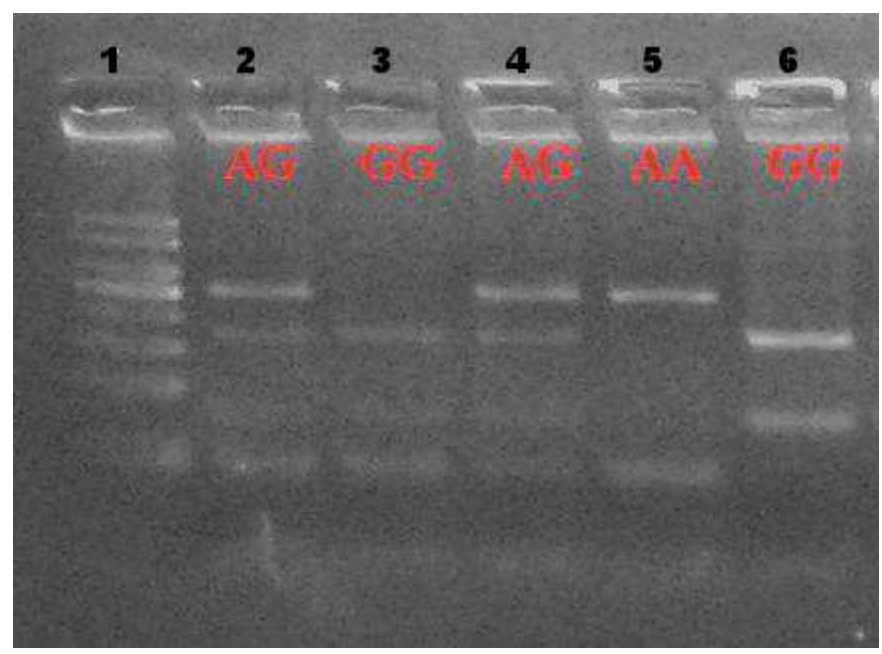

Fig. 2. The product of the digestion - all the variants of the polymorphism in the studied gene. Lane $1-$ DNA ladder, lane 2 and $4-A G$ genotype, lane 3 and $6-G G$ genotype, lane $5-A A$ genotype

Ryc. 2. Produkt trawienia - wszystkie warianty polimorficzne badanego genu. Ścieżka 1 - marker, ścieżki 2 i 4 -genotyp $A G$, ścieżki 3 i 6 -genotyp $G G$, ścieżka 5 - genotyp $A A$

Table 1. The frequency of alleles and genotypes $E R \alpha / B g / l$ in the herds tested Tabela 1. Frekwencja występowania alleli i genotypów $E R \alpha / B g / l$ w badanych stadach

\begin{tabular}{|c|c|c|c|c|}
\hline \multicolumn{4}{|c|}{$E R \alpha / B g l l$} & $\begin{array}{c}\text { Alleles } \\
\text { Allele } \\
\end{array}$ \\
\hline \multicolumn{5}{|l|}{ Jersey } \\
\hline $\begin{array}{l}\text { Genotype } \\
\text { Genotyp }\end{array}$ & $G G$ & $A G$ & $A A$ & $G$ \\
\hline $\begin{array}{l}\text { Frequency } \\
\text { Frekwencja }\end{array}$ & 0.76 & 0.2 & 0.04 & 0.86 \\
\hline \multicolumn{5}{|c|}{ Holstein-Friesian red and white - Holsztyńsko-fryzyjska czerwono-biała } \\
\hline $\begin{array}{l}\text { Genotype } \\
\text { Genotyp }\end{array}$ & $G G$ & $A G$ & $A A$ & $G$ \\
\hline $\begin{array}{l}\text { Frequency } \\
\text { Frekwencja }\end{array}$ & 0.89 & 0.08 & 0.03 & 0.93 \\
\hline
\end{tabular}


By analysing the data shown in the Table 1 , it is visible that the most common genotype is GG in both herds with their frequency being 0.76 (Jersey) and 0.89 (HF). It is important to note that in the HF herd the number of GG cows was higher. A similar tendency is noticeable when it comes to heterozygous animals - in the Jersey herd $(0.2)$ the genotype was observed more frequently than in the HF one (0.08). The frequency of AA genotype was similar in both Jersey and HF herds being 0.04 and 0.03 respectively. The frequency of alleles reflected the genotypes' frequency. The majority of all alleles observed were the $G$ variant in both herds. The less prevalent $A$ allele was more common in Jerseys than in HFs. In the herds tested, the frequency of particular genotypes unequivocally showed that cows with the GG genotype are more commonly chosen by farmers for milk production, even if the selection was based exclusively on phenotypic traits linked with parameters typical for milk yield. The results of milk production in cattle breeds has been analysed in the following study. It showed that the 2 breeds had a significantly different milk yield with the Jersey herd giving roughly $5000 \mathrm{~kg}$ per lactation and the HF red and white yielding over $10000 \mathrm{~kg}$ per lactation.

\section{The association between milk yield and the $E R \alpha / B g / l$ genotype}

The results of milk production during the first 305-day long lactation for the Jersey cattle herd in correlation to the $E R \alpha / B g / l$ genotype are shown in the Table 2. During the first lactation the average milk yield was $5798 \mathrm{~kg}$. No statistically significant differences have been shown. However, homozygous GG cows' milk yield was higher than the $A G$ cows by $197 \mathrm{~kg}$. The $A A$ homozygotes were characterized by having intermediate milk production, however, it is important to note that the group comprised of only 6 cows with this genotype. The rest of the traits as percentage content of fat and protein were on a similar level no matter what genotype the cows were.

Table 2. The efficiency of milk production traits of Jersey cattle, depending on the $E R \alpha / B g / l$ genotype Tabela 2. Wydajność cech mleczności krów rasy jersey, w zależności od genotypu ERa/ Bgll

\begin{tabular}{|c|c|c|c|c|}
\hline \multirow{2}{*}{$\begin{array}{l}\text { Trait } \\
\text { Cecha }\end{array}$} & \multirow{2}{*}{$\begin{array}{l}\text { Herd's average } \\
\text { Średnia stada }\end{array}$} & \multirow{2}{*}{$\begin{array}{c}p \text { value } \\
\text { Wartość } p\end{array}$} & \multicolumn{2}{|c|}{$\begin{array}{l}\text { Genotype } \\
\text { Genotyp }\end{array}$} \\
\hline & & & $A A$ & $A G$ \\
\hline $\begin{array}{l}\text { Milk yield efficiency } \\
\text { Wydajność mleczna [kg] }\end{array}$ & $5798.2 \pm 820.8$ & 0.12322 & $5812.6 \pm 839.9$ & $5692.1 \pm 912.3$ \\
\hline $\begin{array}{l}\text { Fat content } \\
\text { Zawartość tłuszczu [\%] }\end{array}$ & $5.04 \pm 0.49$ & 0.9885 & $5.12 \pm 0.51$ & $4.98 \pm 0.47$ \\
\hline $\begin{array}{l}\text { Protein content } \\
\text { Zawartość białka [\%] }\end{array}$ & $3.74 \pm 0.31$ & 0.854 & $3.69 \pm 0.21$ & $3.82 \pm 0.32$ \\
\hline
\end{tabular}

The results of milk production related traits in first, 305-day long lactation depending on the $E R \alpha / B g / l$ genotype in the HF herd were shown in the Table 3. Because of the low number of cows with a homozygous $A A$ genotype (2), their milk yield efficiency was not presented.

Similarly, as in the Jersey herd, animals with $G G$ genotype had a significantly higher milk yield efficiency than heterozygous $A G$ and homozygous $A A$ ones. The difference, even though not confirmed statistically, was $1610 \mathrm{~kg}$ of milk. The lack of statistical confirmation is most likely to be a result of the study groups being small. The quality components like content of fat and protein were similar regardless of what the cow's genotype was. 
Table 3. The efficiency of milk production traits of HF cattle, depending on the $E R \alpha / B g / l$ genotype Tabela 3. Wydajność cech mleczności krów rasy HF, w zależności od genotypu $E R \alpha / B g l l$

\begin{tabular}{|c|c|c|c|c|}
\hline \multirow{2}{*}{$\begin{array}{l}\text { Trait } \\
\text { Cecha }\end{array}$} & \multirow{2}{*}{$\begin{array}{l}\text { Herd's average } \\
\text { Średnia stada }\end{array}$} & \multirow{2}{*}{$\begin{array}{l}p \text { value } \\
\text { Wartość } p\end{array}$} & \multicolumn{2}{|c|}{$\begin{array}{l}\text { Genotype } \\
\text { Genotyp }\end{array}$} \\
\hline & & & AG & GG \\
\hline $\begin{array}{l}\text { Milk yield efficiency } \\
\text { Wydajność mleczna [kg] }\end{array}$ & $10280.2 \pm 1912.3$ & 0.209 & $9472.1 \pm 989.4$ & $11082.4 \pm 2181.6$ \\
\hline $\begin{array}{l}\text { Fat content } \\
\text { Zawartość tłuszczu [\%] }\end{array}$ & $3.91 \pm 0.48$ & 0.781 & $3.89 \pm 0.49$ & $3.93 \pm 0.51$ \\
\hline $\begin{array}{l}\text { Protein content } \\
\text { Zawartość białka [\%] }\end{array}$ & $3.52 \pm 0.21$ & & $3.53 \pm 0.18$ & $3.51 \pm 0.22$ \\
\hline
\end{tabular}

A wide group of scientists have studied the influence of single nucleotide polymorphism (SNP) on milk yield in cattle. Korean scientists did research on the influence of several SNPs on such milk performance traits as milk yield, fat content and protein content. The research has been run on HF cattle, like in this study. One of the polymorphisms studied, was the one in the regulatory region of $E R$ gene. It has been shown that it is related to milk yield but not to any of the quality traits (Lee et al. 2016). These results confirm the results of this study.

The ER are linked with milk production not only because of their influence on the amount of milk being produced during a single lactation. A correlation between its polymorphisms in the regulatory region and length of lactation after calving, an interval between two following pregnancies and a pregnancy's length, has also been a topic of studies. In the studies mentioned, it has been proven that the GG homozygotes' lactation lasts longer than the $A G$ heterozygoes' and that the homozygotes need less time to regenerate after a calf's separation, before their next pregnancy and also that their pregnancy lasts slightly longer. (Szatkowska et al. 2010). Another study emphasizes importance of the ERs function in the process of developing a mammary gland. A faster development of a gland and its size are correlated with a cow's milk performance efficiency (Capuco et al. 2011).

\section{CONCLUSION}

In summary, it can be stated that there exists a linkage between milk yield of a standard 305 -day long lactation and polymorphisms localised in the regulatory section of the $E R \alpha / B g / l$ gene. Despite the fact that the results of the following study have not been confirmed by statistical analysis, the tendency fora higher milk yield has been observed in cows with the GG genotype in both herds. Due to this, to confirm the association, it is suggested to run further studies in the future.

\section{REFERENCES}

Capuco A.V., Choudhary R.K., Daniels K.M., Li R.W. 2011. Bovine mammary stem cells: Cell biology meets production agriculture. J. Animal. 6, 382-393.

Capuco A.V., Meyer M.J. 2006. Estrogen-dependent responses of the mammary fat pad in prepubertal dairy heifers. J. Endocrinol. 190(3), 819-827.

Connor E.E., Wood D.L. 2005. Chromosomal mapping and quantitative analysis of estrogen-related receptor alpha-1, estrogen receptors alpha and beta and progesterone receptor in the bovine mammary gland. J. Endocrinol. 185(3), 593-603. 
Lande R., Thompson R. 1989. Efficiency of marker-assisted selection in the improvement of quantitative traits. Genetics. 124, 743-756.

Lee Y., Shin D., Lee W., Taye M., Cho K., Park K., Kim H. 2016. The prediction of the expected current selection coefficient of single nucleotide polymorphism associated with Holstein milk yield, fat and protein content. Asian-Austr. J. Anim. Sci. 29(1), 36-42.

Manavathi B., Kumar R. 2006. Steering estrogen signals from the plasma membrane to the nucleus: Two sides of the coin. J. Cell. Physiol. 207(3), 594-604.

Nowaka J.Z., Zawiska J.B. 2004. Receptory i mechanizmy przekazywania sygnału. Warszawa, Wydaw. Nauk. PWN, 604-616. [in Polish]

Primer 3, http://bioinfo.ut.ee/primer3-0.4.0/, access: June 2016.

Szatkowska I., Grzesiak W. 2010. An analysis of CYP19, CYP21 and ER genotypes in Polish Holstein-Friesian cows with regard to the selected reproductive traits. Acta Veter. Brno 80, 65-71.

Abstract. Modern farming asks many questions which science has answers to. While selecting animals for further breeding, many aspects should be taken under consideration, like an animal's phenotypic and genetic features. Marker-assisted selection is a useful tool for judging an animal's genetic value. There are many well-known genetic factors responsible for efficiency of animal production and many of which still need to be studied in more depth. The following study examines the association between $E R \alpha / B g / l$ genotypes and milk performance in cattle. Two breeds were analysed in this study (Jersey and Holstein-Friesian red and white) and from the data gathered there is evidence to suggest that polymorphisms in the gene influences milk yield in these breeds. Three genotypes were identified: $G G, A G, A A$. The data pertaining to milk yield of both herds received from the farmers shows that the efficiency of milk production is the highest in the $G G$ homozygotes and the lowest in the $A G$ heterozygotes. This suggests a strong link between these genetic variants and the effective production of milk. However, to confirm the association between the polymorphic traits of the studied gene and milk production traits, it would be necessary to run a study on a larger group of cattle and to use infomration about their further lactation cycles. 
